\title{
Internet Analysis of Figurative Language in Automotive Advertisement Slogans
}

\author{
Karta Atmaja \\ Sekolah Tinggi Bahasa Asing Cipto Hadi Pranoto, West Java, Indonesia \\ mr.atmaja06@gmail.com
}

DOI: https://doi.org/10.18326/jopr.v4i1.18-28

Copyright $($ The Author (s)

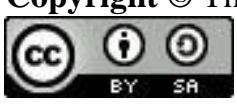

This work is licensed under a Creative Commons Attribution-ShareAlike 4.0 International License.

How to Cite: Atmaja, K. (2022). Internet Analysis of Figurative Language in Automotive Advertisement Slogans. Journal of Pragmatics Research, 4(1), 18-28. doi:https://doi.org/10.18326/jopr.v4i1.18-28

Submission
Track:
Received:
16-11-2021
Final Revision:
01-02-2022
Available online:
02--02-2022
Corresponding
Author:
author
mr.atmaja06@gmail.com

\begin{abstract}
This study aims to figure out what figurative language was utilized in the slogan and assess what that figurative language means in context. The data for this study came from advertising on the internet. The data were analyzed using descriptive qualitative research methods. Qualitative research methods focus on features of a problem's in-depth understanding. This study collects, analyzes, and interprets data through data gathering techniques such as observation and document analysis. In this study, the researcher analyzed twenty-two automotive brand slogans. It showed that there were three slogans using Personification, two slogans using Metaphor, seven slogans using Hyperbole, three slogans using Metonymy, one slogan using Simile, one slogan using Litotes, one slogan using Paradox, one slogan using Synecdoche, and one slogan using Symbols. From these results, it can be concluded that the most widely used figurative languages in the automotive advertising slogans studied are Hyperbole, Personification, and Metonymy.
\end{abstract}

Keywords: Figurative Language, Analyzes, Automotive, Slogan

\section{INTRODUCTION}

Language is a structured communication system or medium used by humans to convey something or express meaning that others can capture by speech, gestures, or writing. Language is a set of arbitrary linguistic symbols used to communicate with other people. (Ronald, 2006) People use language to express their desires, intentions, messages, and information. As a result, the most crucial aspect of advertising is language. 
Advertising is a form of information or message created by a person, institution/agency, or company that conveys a compelling message about a product or service meant for the general public, intending to persuade and influence them to purchase or use the advertised service/product. (O'Neill, 1986) The advertisement also aims to provide information that makes consumers aware of the brand of a product and reminds consumers of a product. The language in the advertisement should be easy to understand and interesting. According to Dyer (2009), advertising implies drawing attention to something or notifying or informing someone of something. In advertising, a company or agency usually uses a slogan that is easy to remember and attracts the audience. (Dyer, 2009)

A slogan is a short word or sentence that consists of several words or sentences that are relatively short, interesting, and easy to remember. A slogan can also be a company's brand identity or personal branding. According to Charles Whittier's book "Creative Advertising," a slogan should be a kind statement about a product or service deserving of repeat advertising; beneficial for the public to remember; and spoken in a style that the public is likely to remember. (Whittier, 1955)

According to Geoffrey N. Leech (1972) in his book "English in Advertising: A Linguistic Study of Advertising in Great Britain," a slogan is a short phrase used by a corporation in its commercials to promote the brand's identity. Slogans, he believes, are more potent than company logos because they are easier to remember and regurgitate. Furthermore, according to the researcher, slogans must clearly explain the fundamental idea of the commercial, i.e., they must be simple to comprehend. According to David P. Rein, an advertising slogan is a "distinct phrase associated with a firm or brand" (Rein 1982: 49). He claims that the tagline, which serves as a summary of the advertising campaign's fundamental premise, must "command attention, be memorable, and be brief" (Rein 1982: 54). (Skorupa \& Dubovičienė, 2015)

Gibbs (2006) states figurative terms are used to describe thoughts and elicit the appropriate emotions in the reader. Figurative language refers to using words or phrases that stray from traditional meanings to convey complex meanings and produces images and beautiful meanings, strengthening and reviving inanimate objects. In addition, as Jay (2003:313) points out, metaphorical language is not meant to be taken literally. He further argues that understanding the meaning of figurative language is challenging because the meaning might be vague and difficult to comprehend at times. (Jay T, 2003). Figurative language is a way to deliver meaning other than the literal meaning of the words. Figurative language generally describes thoughts and evokes the right feelings in the reader. (Gibbs, 2006) Figurative language is one of the most effective devices for producing persuasive discourse that can achieve the ultimate goals of advertising to build readers' motivation and memorability. Figurative language is used often in any form of communication, such as in daily conversation, articles in the newspaper, advertisements, novels, poems, and many more. According to Peter, Figurative Language is a language that has figurative 
meaning and incorporates the speaker's desire to touch the emotions, to cause stock, and to persuade into action. In other words, figurative language is the speakers' language to help them transfer their ideas or thoughts into the audience's minds. (Peter, 2002) Figurative language is one that literally, in a compatible term, forces the readers to attend to the connotation rather than to the denotation. Kreidler (1998: 44-45) on (Wardoyo, 2015) explain the connotation is part of the meaning, the effective or emotional associations are elicited, which not be the same for all people who know and use the word. According to X.J. Kennedy (1991:548), a figure of speech may be said to occur whenever a speaker or writer, for the sake of freshness or emphasis, departs from the usual denotations of words. (Knickerbocker, 1963)

According to Kennedy (1979), figurative language can be divided into comparative, contradictive, and correlative. Comparative figurative language includes personification, metaphor, and simile, while contradictive figurative language includes hyperbole, litotes, paradox, and irony. Correlative figurative language includes metonymy, synecdoche, symbol, allusion, and ellipsis. "Personification is a figure of speech in which an object, an animal, or an abstract phrase (truth, nature) is turned human," writes Kennedy. Metaphor (VPoppel, 2021) is an analogy that compares two things explicitly but in a brief sequence. It signifies that the subject and object share the same characteristics, and the writer uses them to compare them. According to Kennedy (1979), a simile compares two objects, usually denoted by a connective, such as like, then, or like. Hyperbole, according to Kennedy, is the use of exaggeration to emphasize a point. Litotes (Yuan, 2017), is the statement of one is meaning by expressing something that is the polar opposite of one's viewpoint, and it is used to make someone's remarks more emphatic. A statement that appears to be self-contradictory at first but makes sense after more consideration is referred to as a paradox. The irony, according to Kennedy, has a deeper meaning beyond its employment as a rhetorical device. The irony is usually always the result of contrast or disparity between what occurs and what was predicted to occur. Metonymy refers to the use of a word or phrase closely related to the real meaning of the word or phrase. The name of one object is replaced by the name of another closely related object in a figure of speech. (Pfeiffer \& Perrine, 1978) Synecdoche is the use of a portion of anything to represent the entire thing or vice versa. A symbol is an object or action that represents something other than its literal essence. According to Potter, allusion is the metaphorical language that indirectly forwards a person or even to has known one other.

Ellipsis is figurative language in which words or parts of sentences are omitted. (Potter, 1967) Several previous studies were used as reference materials and literature studies in this study, namely as follows: first, the research conducted by Ekoyono (2019) entitled "Analysis of Figurative Language used in English Slogan of Commercial Beverage Products." The context of this research focuses on commercial beverage Products. This study aims to figure out what figurative language is utilized in the automotive slogan and to assess what that figurative language means in the context. 


\section{RESEARCH METHOD}

This research used qualitative descriptive methods. This research was obtained through data collection such as interviews, observations, discussions, document analysis, or documentation by taking pictures or videos. According to Bogdan \& Biklen, qualitative research methods are research methods based on the philosophy of post-positivism, used to examine the condition of natural objects. (Bogdan \& Bilken, 1997). According to Creswell (Creswell 2012), the research design is a pattern that a researcher follows when collecting, evaluating, and interpreting data. When choosing a research design, the researcher should think about what data should be collected and analyzed, as well as how it should be collected and analyzed.

The researcher used observation and documentation. When obtaining data from the situation and condition of the object under study, this observation technique is critical. Then, as part of the documentation technique, researchers gathered references and data reinforcement from sources such as photos or writings found in advertising. For this study, researchers looked for car advertising slogans in internet-based media, such as social media and websites. The researcher then made a list of the slogans, examined them, and compiled the information based on their classification.

\section{RESULTS \& DISCUSSION}

The total slogans that the researchers examined were 20 slogans from 20 automotive brands. The researcher groups the automotive advertising slogans into a table to make it easier for readers to understand the types of figures contained in automotive advertising slogans.

\section{Types of Figurative Language}

Table 1. Types of Figurative Language

\begin{tabular}{|c|c|c|c|}
\hline No. & Branc & Slogans & $\begin{array}{l}\text { Figurative } \\
\text { Language }\end{array}$ \\
\hline 1 & Ferrari & You are the fuel & Metaphor \\
\hline 2 & Porsche & Hugs the road like a mom after graduation & Simile \\
\hline 3 & $\begin{array}{l}\text { Mercedes- } \\
\text { Benz }\end{array}$ & The best or nothing & Paradox \\
\hline 4 & Lamborghini & Discover your beast & Symbol \\
\hline 5 & B M W & Sheer Driving Pleasure & Hyperbole \\
\hline 6 & Audi & Everyone dreams of an Audi & Synecdoche \\
\hline 7 & Bugatti & Right of Common Man & Litotes \\
\hline 8 & Lexus & The relentless pursuit of perfection & Hyperbole \\
\hline
\end{tabular}




\begin{tabular}{|c|c|c|c|}
\hline 9 & Jeep & The sun never sets on the mighty jeep & Hyperbole \\
\hline 10 & Mini & You Don’t Need A Big One to Be Happy & Metaphor \\
\hline 11 & Jaguar & Born to Perform & Personification \\
\hline 12 & Volkswagen & $\begin{array}{l}\text { If only everything in life was as } \\
\text { reliable as a Volkswagen }\end{array}$ & Metonymy \\
\hline 13 & Chevrolet & The heartbeat of America & Metonymy \\
\hline 14 & Peugeot & The drive of your life & Hyperbole \\
\hline 15 & Mazda & Subdue the road, and free YOUR SPIRIT & Hyperbole \\
\hline 16 & Hyundai & Always there for you & Hyperbole \\
\hline 17 & Daihatsu & Light you up & Hyperbole \\
\hline 18 & Ford & The Best Never Rest & Personification \\
\hline 19 & Toyota & The car in front is a Toyota & Metonymy \\
\hline 20 & Honda & The Power of Dream & Personification \\
\hline
\end{tabular}

All of the slogans with figurative language were assessed for their contextual meaning in this study, as follows:

\section{Datum 1: "You are the fuel" (Ferrari)}

The researcher discovered that Metaphor is a type of figurative language used in this slogan based on the slogan. Metaphor is similar to the simile in terms of meaning. This mode of speech compares two things as well, but without using the words "like," "as," or "then." Metaphor is created by comparing two objects using some form of the verb or to be. The brand owner equates people who drive vehicles to fuel in this tagline, "You are the fuel."

\section{Datum 2: "Hugs the road like a mom after graduation" (Porsche)}

The researcher discovered that Simile is a type of figurative language used in this slogan based on the slogan. A simile compares two things, usually denoted by a connective, such as then or resembles. According to this phrase, driving a Porsche is a relaxing experience since the car fades into the road like a mother's embrace.

\section{Datum 3: "The best or nothing" (Mercedes-Benz)}

The researcher demonstrated that this slogan contains figurative language that is paradoxical. A paradox is a combination of two items that comprise contradictory claims that are both true in some way. According to the tagline it's considered a paradox because the phrases 
"best" and "not at all" contradict one other. This phrase draws comparisons that can't be made because the option is either best or worst.

\section{Datum 4: "Discover your beast" (Lamborghini)}

The researcher discovered that Symbol is a type of figurative language used in this slogan based on the phrase. When an object represents something else, it is called a symbol. It might convey a desired outcome or meaning. A word, place, character, or another thing can be used as a symbol. The brand owner claims that a Lamborghini car is as much of a "beast" as the company's logo, which is a "bull." Wild creatures are frequently associated with being ferocious, courageous, and possessing various vital attributes. Similarly, the Lamborghini car, regarded as one of the most luxurious automobiles, has a speed comparable to that of a wild animal.

\section{Datum 5: "Sheer Driving Pleasure" (BMW)}

Based on the phrase, the researcher discovered that Hyperbole is a figurative language used in the slogan. Hyperbole is an overblown statement. This figure of speech employs claims that aren't true or that aren't being followed through. It uses a vocabulary that is both excessive and illogical. This tagline is known as Hyperbole since it makes driving an automobile appear to be a simple pleasure.

\section{Datum 6: "Everyone dreams of an Audi" (Audi)}

According to the research, synecdoche is a type of figurative language seen in this slogan. Synecdoche is a term that refers to the use of a component of anything to represent the entire thing or vice versa. The term "everyone" in this tagline refers to a select group of people who, according to a survey, dream of owning an Audi car. It does not refer to the entire world's population.

\section{Datum 7: "Right of Common Man" (Buggati)}

The study demonstrated that Litotes is a figurative language in the phrase based on the slogan. Litotes express one's message by stating something that is the polar opposite of what one is thinking. It is used to make someone's words more strong. In this phrase, it is referred to as litotes since Bugatti automobiles are not intended for the "Common Man." Because, as many people are aware, the Buggati automobile is one of the Hyper Sports Cars that only a select few can afford.

\section{Datum 8: "The relentless pursuit of perfection" (Lexus)}

According to the researcher, Hyperbole is a type of figurative language used in this slogan. A statement that has been overstated is known as Hyperbole. This figure of speech uses statements 
which not really happen or not doing. It uses words that are extreme and do not make sense. This slogan is called Hyperbole because it seems as if the pursuit of perfection is a Lexus car.

\section{Datum 9: "The sun never sets on the mighty jeep" (Jeep)}

Based on the slogan, the researcher discovered that Hyperbole is a type of figurative language used. An overblown statement is referred to as Hyperbole. This figure of speech employs claims that aren't true or aren't being followed through. It uses words that are extreme and do not make sense. This slogan is called Hyperbole because basically, the sun will still set at night. And for the word "mighty" is used as if the car is a person full of bravery and courage.

\section{Datum 10: "You Don't Need A Big One to Be Happy" (Mini Cooper)}

The researcher discovered that Metaphor is a type of figurative language used in this slogan based on the slogan. Metaphor is a statement that one thing is not the same as another in a literal sense. It doesn't employ "like" or "as" to connect sentences. It indicates that a metaphor only makes sense when the parallels between the two objects are apparent or when the relationship is understood. According to this statement, we do not need considerable things to be happy, but owning a car is also a significant thing.

\section{Datum 11: "Born To Perform" (Jaguar)}

According to the researcher, Personification is a figurative language used in this slogan. A figure of speech in which a thing, an animal, or an abstract concept (truth, nature) is turned human is known as Personification. Personification impacts how readers imagine things and piques their interest in the topic. Personification is the name given to this slogan since it provides the car with human features. Where the Jaguar car is called "Born to Perform." The word "born" is expressed for living things that reproduce. And the word "perform" is an action that humans usually do in entertaining. But in this slogan, the meaning is that the Jaguar car was created to show good looks and also good engine quality.

\section{Datum 12: "If only everything in life was as reliable as a Volkswagen." (Volkswagen)}

Based on the phrase, the researcher discovered that Metonymy is a type of figurative language used in this slogan. Metonymy is the usage of a word or phrase closely related to the meaning. One object's name is replaced by another closely related to it in a figure of speech. This figurative language usually uses the object's name, such as person name, brands name, and another object related to replacing the word. The brand owner presupposes that everything is as reliable as a Volkswagen car in this slogan. 


\section{Datum 13: "The heartbeat of America" (Chevrolet)}

The researcher discovered that the tagline uses Metonymy as a figurative language. Metonymy is the usage of a word or phrase closely related to the meaning. It's a figure of speech in which one object's name is replaced by another closely related to it. This figurative language usually uses the object's name, such as person name, brand name, and another object related to replacing the word. In this slogan, the term "America" refers to the country that created the Chevrolet car. The "heartbeat" in question is a phrase that refers to one of the icons or technological inventions invented by America.

\section{Datum 14: "The drive of your life." (Peugeot)}

Based on the phrase, the researcher discovered that Hyperbole is a figurative language used in the slogan. Hyperbole is an overblown statement. This figure of speech uses statements that do not happen or not doing. It uses powerful words and does not make sense. This slogan is called Hyperbole because humans are what drive cars. It's not a machine that moves people.

\section{Datum 15: "Subdue the road, and free YOUR SPIRIT" (Mazda)}

According to the researcher, Hyperbole is a type of figurative language used in this slogan. Exaggerated statements are referred to as Hyperbole. This figure of speech uses statements which not really happen or not doing. It uses words that are extreme and do not make sense. This slogan is called "Hyperbole" because the language "subdue the road" as if the road is like a living creature that can be tamed and controlled. And "free your spirit, as if we have control to free our spirit. So what is meant in this slogan is a sense of satisfaction when driving a Mazda car.

\section{Datum 16: "Always there for you" (Hyundai)}

Based on the slogan, the researcher discovered that Hyperbole is a type of figurative language used. Exaggerated statements are known as Hyperbole. This figure of speech uses statements which not really happen or not doing. It uses words that are extreme and do not make sense. This slogan is called "hyperbole" because it seems that whenever, wherever, and in all activities, Hyundai cars can be relied on.

\section{Datum 17: "Light you up" (Daihatsu)}

Based on the slogan, the researcher discovered that Hyperbole is a type of figurative language used. Exaggerated statements are known as Hyperbole. This figure of speech uses statements that do not happen or are not doing. It uses powerful words and does not make sense. In this slogan, "Hyperbole" because if a car can be a human being is a fire that can be ignited. 


\section{Datum 18: "The best never rest" (Ford)}

The study demonstrated that the tagline uses Personification as a metaphorical language. Giving a human face to an animal, an object, or an abstract concept is known as Personification. An object or animal acts like a person. In this slogan, the brand owner claims that Ford cars never rest. Rest is a state of calm, relaxation without emotional stress, and free from anxiety (anxiety). The word "rest" is usually only used for humans. Where when people stop doing their jobs or activities.

\section{Datum 19: "The car in front is a Toyota" (Toyota)}

Based on the phrase, the researcher discovered that Metonymy is a type of figurative language used in this slogan. Metonymy is the usage of a word or phrase closely related to the meaning. It's a figure of speech in which the name of one object is replaced by the name of another object that's closely related to it. This figurative language usually uses the object's name, such as person name, brands name, and another object associated with replacing the word. The car in front is too, in this slogan, but the brand is "Toyota."

\section{Datum 20: "The power of dreams" (Honda)}

According to the researcher, Personification is a figurative language used in this slogan. A figure of speech in which a thing, an animal, or an abstract concept (truth, nature) is turned human is known as Personification. Personification impacts how readers imagine things and piques their interest in the topic. In this slogan, dreams are called having power, where we know that dreams are subconscious experiences that involve seeing, hearing, thinking, feeling, or other senses, especially during sleep. At the same time, strength requires effort or movement. So the power of this dream catchphrase results from the effort put into making dreams come true.

The Number of Figurative Languages found in car advertising slogans

Table 2. The Number of Figurative Languages

\begin{tabular}{|c|c|c|c|c|}
\hline No. & $\begin{array}{c}\text { Types of } \\
\text { figurative } \\
\text { language }\end{array}$ & $\begin{array}{l}\text { Number of } \\
\text { Figurative }\end{array}$ & $\begin{array}{l}\text { Figurative Language - } \\
\text { Inspired Slogans }\end{array}$ & Brands \\
\hline \multirow[t]{3}{*}{1} & Personification & 3 & "Born To Perform" & Jaguar \\
\hline & & & "The best never rest" & Ford \\
\hline & & & "The power of dreams" & Honda \\
\hline \multirow[t]{2}{*}{2} & Metaphor & 2 & "You are the fuel" & Ferrari \\
\hline & & & $\begin{array}{l}\text { "You Don't Need A Big One } \\
\text { to Be Happy" }\end{array}$ & Mini Cooper \\
\hline \multirow[t]{7}{*}{3} & Hyperbole & 7 & "Sheer Driving Pleasure" & BMW \\
\hline & & & $\begin{array}{l}\text { "The relentless pursuit of } \\
\text { perfection" }\end{array}$ & Lexus \\
\hline & & & $\begin{array}{l}\text { "The sun never sets on the } \\
\text { mighty jeep" }\end{array}$ & Jeep \\
\hline & & & "The drive of your life" & Peugeot \\
\hline & & & $\begin{array}{c}\text { "Subdue the road, and free } \\
\text { your spirit" }\end{array}$ & Mazda \\
\hline & & & "Always there for you" & Hyundai \\
\hline & & & "Light you up" & Daihatsu \\
\hline
\end{tabular}




\begin{tabular}{|c|c|c|c|c|}
\hline 4 & Metonymy & 3 & $\begin{array}{l}\text { "If only everything in life was } \\
\text { as reliable as a Volkswagen } \\
\text { "The heartbeat of America" } \\
\text { "The car in front is a Toyota" }\end{array}$ & $\begin{array}{l}\text { Volkswagen } \\
\text { Chevrolet } \\
\text { Toyota }\end{array}$ \\
\hline 5 & Simile & 1 & $\begin{array}{l}\text { "Hugs the road like a mom } \\
\text { after graduation" }\end{array}$ & Porche \\
\hline 6 & Litotes & 1 & "Right of Common Man" & Buggati \\
\hline 7 & Paradox & 1 & "The best of nothing" & $\begin{array}{l}\text { Mercedez } \\
\text { Benz }\end{array}$ \\
\hline 8 & Synecdoche & 1 & $\begin{array}{c}\text { "Everyone dreams of an } \\
\text { Audi" }\end{array}$ & Audi \\
\hline 9 & Symbol & 1 & "Discover your beast" & Lamborghini \\
\hline
\end{tabular}

There are three slogans using Personification, two slogans using Metaphor, seven slogans using Hyperbole, three slogans using Metonymy, one slogan using Simile, one slogan using Litotes, one slogan using Paradox, one slogan using Synecdoche, and one slogan using Symbol.

\section{CONCLUSION}

Based on the results, the analysis of 20 slogans from 20 brands on manufactured automobile products, discovered 3 slogans that use Personification, 2 slogans that use Metaphor, 7 slogans that use Hyperbole, 3 slogans that use Metonymy, 1 phrase that uses Simile, 1 slogan that uses Litotes, 1 slogan that uses Paradox, 1 slogan that uses Synecdoche, and 1 slogan that uses Symbol, and Hyperbole, Personification, and Metonymy are the three most common figurative languages analyzed in-car advertising slogans.

\section{REFERENCES}

Brown, L. A., \& Lynn, R. W. (1976). Reviews : Oxford Advanced Learner's Dictionary of Current English, Third edition. An S Hobby, with the assistance of A P Cowie and J Windsor Lewis Oxford University Press, 1974. xxvii, 1056 pp. RELC Journal, 7(1), 77-79. https://doi.org/10.1177/003368827600700111

Charles Whittier.(1955).Creative Advertising. 453-455. https://doi.org/https://doi.org/10.2307/1248257

Charles O’Neill. (1986). The Language of Advertising.

DiYanni, R. (2004). Literature Approaches Fiction, Poetry, and Drama. The McGraw-Hill Companies.

Dyer. (2009). Advertising as Communication. https://doi.org/https://dx.doi.org/10.4324/9780203328132 
Gibbs, R. W. (2006). Figurative Language. Elsevier Ltd. https://doi.org/https://dx.doi.org/10.1016/B978-012369374-7/50022-5

Jay T. (2003). The psychology of language. Prentice-Hall.

Kennedy, X. (1983). Literature: An Introduction to Fiction, Poetry, and Drama. Little Brown Company.

Knickerbocker, K.L. \& Reninger, H.W. (1963). Interpreting Literature. New York, Holt, Rinehart and Winston.

Perrine, L. (1978). Sound and sense: An introduction to poetry. Harcourt, Brace \& World Inc. https://doi.org/https://doi.org/10.2307/3188611

Peter. (2002). Figurative language and semantics. Little Brown and Company.

Potter. (1967). Elements of Literature. The Odyssey Press.

Ronald, W. (2006). An Introduction to Sociolinguistics (5th ed.). BLACKWELL PUBLISHING. http://staffnew.uny.ac.id/upload/132107096/pendidikan/Book+for+Sociolinguistics.pdf

Skorupa, P., \& Dubovičienè, T. (2015). Linguistic Characteristics of Commercial and Social Advertising Slogans. Coactivity: Philology, Educology, 23(2), 108-118. https://doi.org/10.3846/cpe.2015.275

Stern, J. (2008). Figurative Language. in The Blackwell Guide to the Philosophy of Language (pp. 168-185). Blackwell Publishing Ltd. https://doi.org/10.1002/9780470757031.ch9

Sugiyono. (2016). Metode Penelitian Kuantitatif, Kualitatif, dan R\&D. ALFABETA.

Wardoyo, N. (2015). The Types and Interpretation Figurative Language Used in Pirates of Caribbean on Stranger Tides Movie Manuscript. CNR-ISTI Technical Report, 3(2), 356-369. 